\title{
Synthetic or Reformulated Fuels: a Challenge for Catalysis*
}

\author{
Ph. Courty ${ }^{1 * *}$, P. Chaumette ${ }^{1}$ and C. Raimbault ${ }^{1}$ \\ 1 Institut français du pétrole, 1 et 4, avenue de Bois-Préau, 92852 Rueil-Malmaison Cedex - France \\ e-mail: philippe.courty@ifp.fr \\ * Updated from a plenary lecture presented by Ph. Courty at the 3rd TOCAT Conference (Tokyo, July 19-24, 1998) \\ and issued in Studies in surface science and catalysis, 121, 41-50, 1999. \\ ** To whom correspondence should be adressed
}

Résumé - Carburants de synthèse ou reformulés : un défi pour la catalyse - Malgré des réserves prouvées en pétrole et en gaz du même ordre de grandeur, la contribution de la chimie du gaz de synthèse à la production de carburants reste marginale, alors que l'industrie du raffinage est confrontée à des contraintes majeures : évolution de la demande, durcissement des spécifications des produits et contraintes environnementales. Cependant, la conversion chimique du gaz, via la chimie du gaz de synthèse, fournit des produits stratégiques (e.g. méthanol) parmi lesquels les carburants propres (éthers, produits FischerTropsch) devraient se développer bien que les investissements requis soient lourds, notamment pour la production du gaz de synthèse. Les principaux défis, et les voies de progrès correspondantes concernant les catalyseurs et les technologies, sont présentés pour la synthèse Fischer-Tropsch et la reformulation à long terme des carburants. Parmi d'autres, le contrôle de la croissance de chaine (synthèse Fischer-Tropsch), l'amélioration des produits du FCC: essence et LCO pour le pool Diesel, constituent des défis majeurs pour lesquels des progrès importants en matière de catalyseur et de technologie sont attendus. Enfin, une étude économique ciblée sur la production de carburant Diesel met en lumière la presque identité des coûts de production du carburant Diesel reformulé (ex-mélanges GO de distillation directe et LCO), et du carburant Diesel ex-synthèse Fischer-Tropsch lorsque du gaz naturel à faible coût est disponible.

Dans le futur, les distillats moyens ex-synthèse Fischer-Tropsch devraient représenter quelques pour-cent (5-150 Mt) des 1700 à $2000 \mathrm{Mt}$ de distillats moyens pour transports, attendus du raffinage. Toutefois, ils constitueront, à terme, une fraction obligatoire du pool carburant Diesel, dans la mesure où les coûts d'investissement de la technologie Fischer-Tropsch diminueront de façon significative.

Mots-clés : pétrole, gaz, chimie du gaz de synthèse, synthèse Fischer-Tropsch, reformulation des carburants, pool Diesel, catalyseur, technologie, distillats moyens, raffinage, données économiques.

Abstract - Synthetic or Reformulated Fuels: a Challenge for Catalysis - Despite comparative figures for wordwide crude oil and natural gas proven reserves, present time contribution of syngas chemistry to motorfuels remains marginal when the refining industry is faced to main constraints: market demand evolution, stringent specifications and environmental issues. Actually natural gas upgrading via syngas chemistry yields key products (e.g. methanol) among which clean motorfuels (ethers, FT products) should develop despite the huge investments required, mostly for syngas production. Main challenges and corresponding issues for catalysts and related technologies are identified for Fischer-Tropsch synthesis and motorfuels long-term reformulation. Among other, mastering the chain-growth (FT synthesis) improving the FCC products: gasoline, and LCO for Diesel pool. All these issues need 
significant progresses in catalyst and technology to be solved. Lastly, our economical study, focused on Diesel-fuel production, shows up that clean diesel (from SR-LCO mixtures) and FT Diesel reach similar production costs when cheap NG is available.

In the future FT middle distillates should amount to a few percent (5-150 Mt) of the 1700-2000 Mt of transport middle distillates expected from oil refining. However they should more and more be a compulsory part of diesel pool if the level of investment for an FT process continues to decrease significantly. Keywords: crude oil, natural gas, syngas chemistry, Fischer-Trospch synthesis, mortorfuels reformulation, Diesel pool, catalyst, technology, middle distillates, oil refining, economics.

\section{INTRODUCTION}

Natural gas proven resources are still increasing and reached 133 Gtep which amounted to $98 \%$ of oil resources in 1995 [1]. Most of these resources are located in Eastern Europe (CEI) and Middle Eastern countries (Iran, Qatar, Abu Dhabi, Kuwait) [1].

In the mean time, the refining industry is facing three main constraints:

- market demand evolution towards more and more clean middle distillates;

- more stringent specifications on sulfur, aromatics, cetane and octane indexes;

- environmental issues: pollution control on gaseous emissions (including $\mathrm{CO}_{2}$ ) as well as on liquid and solid wastes.

In view of the fact that the present-time contribution of syngas chemistry to motorfuels remains marginal, to what extent a competition might occur beetween clean and reformulated fuels?

\section{THE CHEMICAL CONVERSION OF NATURAL GAS}

Syngas can easily be synthesized from natural gas and can be transformed to motorfuels through many different pathways (Fig. 1). Gasoline as well as ethers can be prepared from methanol, and dimethyl ether has recently been suggested as a substitute to standard Diesel-fuel by Amoco and Topsoe [2].

Fischer-Tropsch synthesis dates back to 1923, with the discovery of an efficient catalyst to convert synthesis gas into hydrocarbons mixtures. After coal-based synthetic fuels production during the second world war in Germany, and later in South Africa (Sasol), the energy crisis of the 1970's and 1980's renewed the interest towards the conversion of the increasing remote natural gas reserves to liquid fuels $[1,3]$.

Between 1984 and 1988, IFP and Idemitsu Kosan demonstrated their modified Fischer-Tropsch process for alcohols production in Japan, under Rapad subsidy [4]. In 1993, two pioneering gas conversion plants started their operations: one by Shell in Malaysia, another one in South Africa (Mossgas). Other companies, such as Exxon, Statoil,

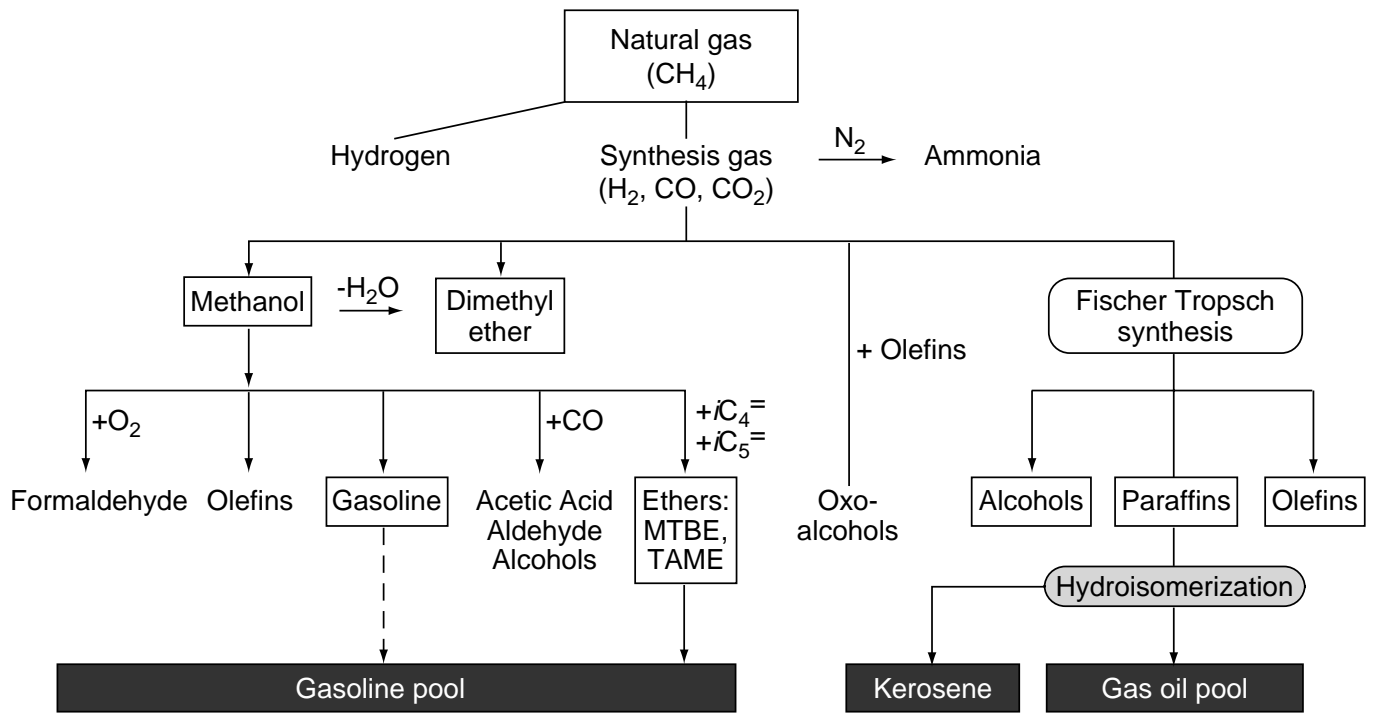

Figure 1

Chemical conversion of natural gas; contribution of syngas chemistry to motorfuels. 
Sasol, Syntroleum and IFP are involved in the development of a new generation of natural gas based Fischer-Tropsch processes [1].

A high quality Diesel-fuel or kerosene, free from sulfur, aromatics or heavy metals can be synthesized through the Fischer-Tropsch process and hydroisomerization of the paraffins obtained. The Diesel oil prepared through FischerTropsch presents a very high cetane number (over 75) and the kerosene a smoke point over 50 .

The integrated Fischer-Tropsch process includes three steps (Fig. 2). The first one allows to transform natural gas into syngas, and is followed by the Fischer-Tropsch synthesis itself. The heavy paraffins obtained in the second step are transformed into diesel oil, kerosene and lube oils in the last hydroisomerization step.

The existing Fischer-Tropsch plant in Bintulu (Malaysia) built by Shell [5] needed an investment of around $\$ 55000 /$ bpd of capacity. Technological improvements and larger overall plant capacities allows to decrease this level of investment to about $\$ 35000 /$ bpd capacity. Since $55 \%$ of total investments are linked to the syngas production section, whereas the Fischer-Tropsch synthesis and the hydroisomerization only represent $30 \%$ and $15 \%$ respectively, there are at present strong incentives to develop new technologies for syngas generation.

Partial oxidation alone, or in combination with steam reforming, seems to be the best choice at present $[1,5]$, but the POX process needs pure oxygen. Savings could be achieved through oxygen separation from air with dense membranes inside a POX reactor. Cryogenic separation of oxygen, an efficient but expensive technology, would then be avoided. This challenging oxygen separation with membranes is actively studied through a joint venture between Amoco, BP, Praxair, Sasol and Statoil (ceramic membranes) and by Air Products under a DOE contract (ionic membranes). Cuts on investments as high as $25 \%$ are expected.

Adaptation to the Fischer-Tropsch process of the autothermal reforming process used for methanol (ATR, [6]), and in which partial oxidation (POX) and steam-reforming (SR) are integrated in a single reactor, could be another way to cut down investments.

Although the Fischer-Tropsch step only represents $30 \%$ of total investments, improvements of this old technology are still needed (Table 1). The Fischer-Tropsch synthesis is catalyzed by cobalt or iron based catalyst, cobalt being more suitable for kerosene and Diesel-fuel production. This reaction is highly exothermic and leads to a wide linear paraffin distribution, due to a Schulz-Flory type chain growth mechanism. The catalyst performances strongly depend on operating conditions, catalyst and reactor technology.

New cobalt based catalysts allow to reach higher wax productivities in the Fischer-Tropsch section, thanks to the use of promoters such as ruthenium. Silica and alumina supports, sometimes doped by zirconia or titania, help to maintain a good cobalt dispersion, and to obtain the right paraffin distribution to be sent to the hydroisomerization section.

Cobalt being far less active than iron in the water gas shift reaction, water is the main by product obtained and $\mathrm{CO}_{2}$

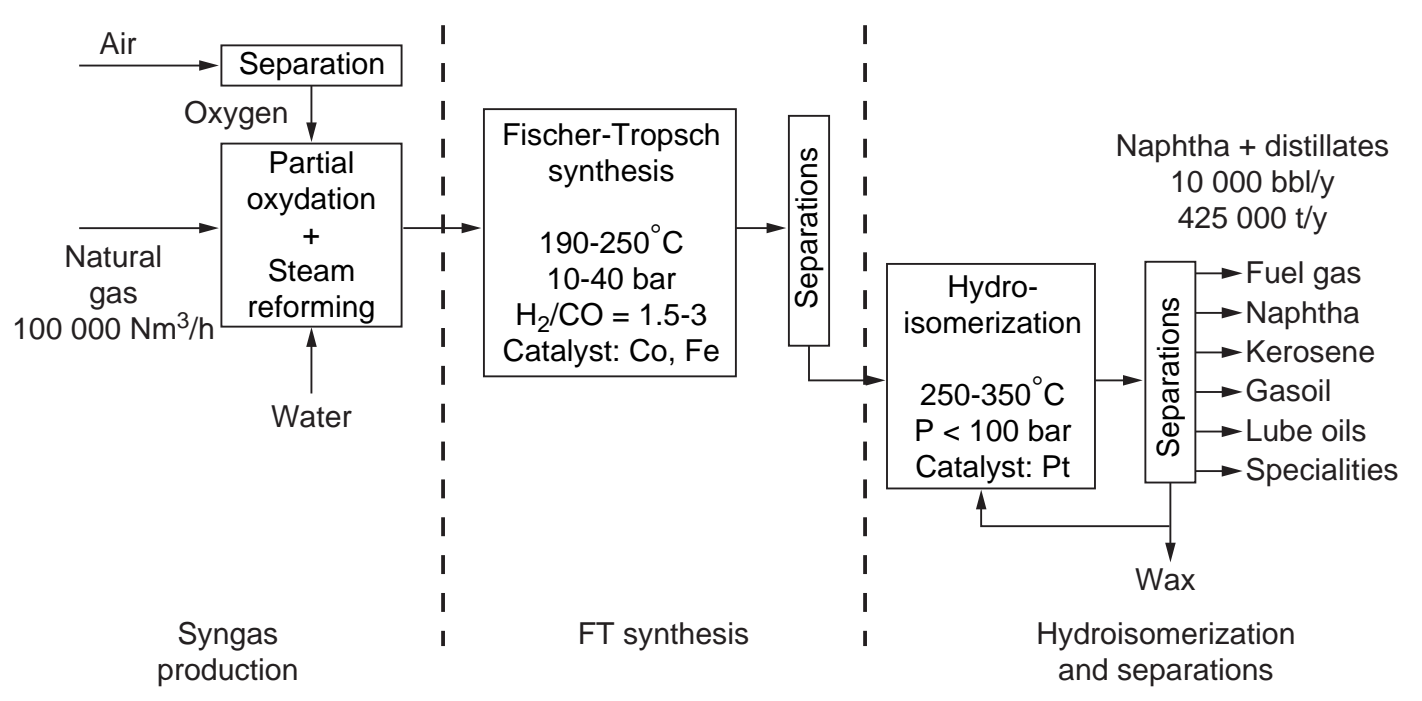

Figure 2

FT synthesis; the integrated gas to liquid process. 
formation remains very low. This small amount of $\mathrm{CO}_{2}$ can eventually be recycled to the syngas production section.

TABLE 1

Fischer-Tropsch synthesis; remaining issues

\begin{tabular}{|c|c|}
\hline Challenges & Issues \\
\hline Activity & $\begin{array}{l}\text { Optimized metal-carrier } \\
\text { interaction } \\
\text { Slurry technology }\end{array}$ \\
\hline $\begin{array}{l}\text { Control of light alkanes formation } \\
\text { (above SF distribution) }\end{array}$ & $\begin{array}{l}\text { Isothermal reaction } \\
\text { Bimetallic catalysts with } \\
\text { optimized particle size } \\
\text { (dispersion) }\end{array}$ \\
\hline $\begin{array}{l}\text { Shift conversion }\left(\mathrm{CO}_{2} \text { or } \mathrm{H}_{2} \mathrm{O}\right. \\
\text { as by-products?) }\end{array}$ & Low WGS Activity with Co \\
\hline By-products (alcohols, olefins) & $\begin{array}{l}\text { Dedicated catalyst formulae } \\
\text { with optimized op. conditions }\end{array}$ \\
\hline Mastering the chain-growth & $\begin{array}{l}\text { Cobalt/zeolites fails to success: } \\
\text { hydroisom. mandatory? }\end{array}$ \\
\hline
\end{tabular}

Despite the progress accomplished, there is still a need for a further increase of activity, together with a mastering of the heat produced. The use of slurry reactors, rather than multitubular fixed bed ones, should help in this respect. However, this technology has only been proven at a scale of around 2400 bpd at Sasol I, in the case of the FischerTropsch process.

There would also be an interest in performing the FischerTropsch and the hydroisomerization reaction in a single step. There have been attempts to do so by using cobalt/zeolites catalysts, but the shape selectivity of zeolites does not operate on long chain paraffins and leads to the transformation of olefinic intermediates into aromatics, which are not desired in the final fuels. Thus, a separate hydroisomerization step cannot be avoided for the time being.

\section{GASOLINE}

The gasoline pool is made of the following bases:

- liquid petroleum gases (LPG); mostly $\mathrm{C}_{4}$;

- isomerate $\left(\mathrm{C}_{4}-\mathrm{C}_{6}\right.$ paraffins);

- reformate $\left(\mathrm{C}_{5}-\mathrm{C}_{12}\right.$ hydrocarbons); mainly aromatics;

- hydrocracking gasoline $\left(\mathrm{C}_{5}-\mathrm{C}_{12}\right.$ hydrocarbons), mainly paraffins and naphthenes;

- gasoline from thermal conversion $\left(\mathrm{C}_{5}-\mathrm{C}_{12}\right.$ hydrocarbons), mainly paraffins and naphthenes;

- alkylate $\left(\mathrm{C}_{5}-\mathrm{C}_{12}\right.$ paraffins);

- polymerisation gasoline $\left(\mathrm{C}_{5}-\mathrm{C}_{12}\right.$ olefins);

- ethers $\left(\mathrm{C}_{5}-\mathrm{C}_{6}-\mathrm{C}_{7}\right)$.
In view of their MON and RON figures, a limited number: alkylate, reforming, ethers, exceed the target. Isomerates meet the target when FCC gasoline, hydrocracking (HCK) gasoline and SR naphtha are far below.

Figure 3 plots octane vs aromatics content. Apart from isomerate and alkylate, very rich in double-branched paraffins with high octane ratings, best MON figures of other bases correspond to aromatic-rich cuts. This situation makes it difficult to meet the main gasoline constraints of the years 2005 and over: limited amount of olefins (6-14\%) aromatics (25-35\%) and sulfur (30-50 ppm). These constraints imply a drastic evolution with reference to conventional gasoline formulation, as seen in Table 2. Main changes deal with a severe decrease of aromatics (reforming and FCC gasoline) olefins (FCC and poly gasoline) sulfur (FCC gasoline) when a limited increase of oxygen content will possibly favor alcohols at the expense of ethers [4].

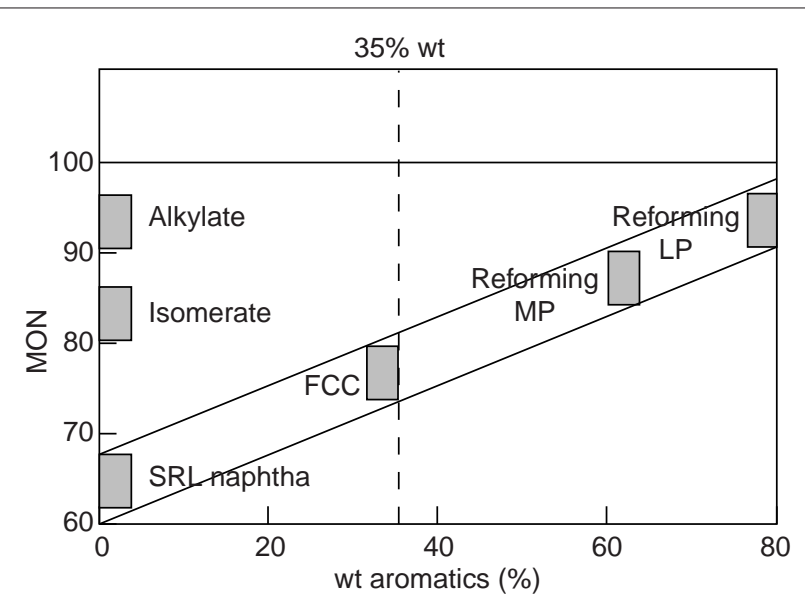

Figure 3

Gasoline pool; octane vs aromatics.

TABLE 2

Typical gasoline pool composition (United States) and its possible evolution

\begin{tabular}{l|c|c|c|c}
\hline \multirow{2}{*}{} & \multirow{2}{*}{$\begin{array}{c}\text { Conventional } \\
\text { gasoline }\end{array}$} & \multicolumn{2}{|c|}{ Reformulated } & \multirow{2}{*}{ Evolution } \\
\cline { 3 - 4 } & 5.5 & 3.5 & 2.0 & $\boldsymbol{\searrow}$ \\
\hline Butanes & 5.5 & 11.6 & 11.6 & $\boldsymbol{\nearrow}$ \\
Isomerate & 33.0 & 28.1 & 14.0 & $\boldsymbol{\searrow}$ \\
FCC gasoline & 1.9 & 3.5 & 15.8 & $\boldsymbol{\nearrow}$ \\
HCK gasoline & 1.0 & 1.4 & 6.6 & $\boldsymbol{\nearrow}$ \\
Poly gasoline & 40.3 & 24.6 & 11.6 & $\boldsymbol{\searrow}$ \\
Reformate & 3.4 & 10.5 & 10.8 & $\boldsymbol{?}$ \\
Ethers (MTBE) & 9.4 & 16.5 & 27.6 & $\boldsymbol{\nearrow}$ \\
Alkylate & 100 & 100 & 100 & \\
\hline
\end{tabular}


Issues for gasoline pool reformulation will arise from catalysts and technology progresses as seen in Table 3. Indeed the ideal environmentally friendly gasoline would be made of isoparaffins and posibly of alcohol or ethers (10-15\%), which strongly pushes forward the alkylate demand. However, more $i \mathrm{C}_{4}\left(\mathrm{C}_{4}\right.$ isomerisation) $\mathrm{C}_{4}=$ and $\mathrm{C}_{5}=$ olefins (dehydrogenation, improved steam cracking, dedicated FCC) would be needed, when the main demand concerns a new solid acid alkylation catalyst sought after together with a competing technology and attractive economics.

\section{TABLE 3}

Gasoline pool reformulation; main constraints and issues

\begin{tabular}{l|l}
\hline Constraints & \multicolumn{1}{c}{ Issues } \\
\hline Benzene & $\begin{array}{l}\text { - Improved reforming catalyst (HDA) with } \\
\text { optimized process conditions } \\
\text { - Benzene saturation or alkylation }\end{array}$ \\
\hline Aromatics & $\begin{array}{l}\text { - New } \mathrm{C}_{7}-\mathrm{C}_{8} \text { isomerization catalysts: activity and } \\
\text { mostly selectivity to get stability }\end{array}$ \\
\hline Sulfur & $\begin{array}{l}\text { - Deep HDT of FCC feedstocks } \\
\text { - Selective desulfurization of FCC gasoline (control } \\
\text { of hydrogenation to limit octane losses) }\end{array}$ \\
\hline Oxygen & $\begin{array}{l}\text { - Improved skeletal isomerization catalysts }\left(\mathrm{C}_{4}-\mathrm{C}_{5}\right) \\
\left.\text { - New etherification technology (IFP Catacol }{ }^{\circledR}\right) \\
\text { - Alcohols? }\end{array}$ \\
\hline
\end{tabular}

\section{DIESEL OIL}

For the Diesel pool, the main challenges (Fig. 4) deal with cetane indexes (> 50) and sulfur content (less than $0.045 \%$ ). Apart from gas oil cut from HCK and in the future FT gas oil, none of the other bases meet the specifications since they show a low cetane and high di- and polyaromatics and sulfur contents. In fact, Diesel oil bases have very different properties. Diesel cuts from conversion processes have high aromatic and sulfur contents, with low cetane indexes, when diesel cuts from HCK contain no aromatics, have a very high cetane $(\geq 70)$ and a very low sulfur content $(<0.01 \%)$. Key challenges concern LCO from FCC and gas oil from thermal conversion units: a very deep desulfurization is needed with polyaromatics hydrogenation to monoalkylaromatics, monoalkylnaphthenes and slightly branched paraffins. This should lead to a significant cetane improvement, however required at a competitive cost.

Actually, main Diesel oil constraints of 2005 years will be difficult to meet: high cetane number $(>53)$, low sulfur content $(<0.005 \%)$, possible limitations of $\mathrm{di}-$ and polyaromatics content (1-6\%), density and heaviest ends. As for premium gasoline, issues for diesel pool improvement will arise from catalyst and technology progresses as seen in Table 4. A good example of Diesel pool improvement is that of pure LCO using the two step IFP hydrotreating process [7]. In a first stage (Table 5) a very deep hydropurification lowers sulfur and nitrogen far below $0.005 \%$ under moderate pressure followed in a second stage by a deep aromatics hydrogenation on a sulfur-resistant noble metal catalyst. A significant cetane increase is noticed and (di+triaromatics) content becomes practically nil. Medium term issues will be to further improve the cetane number via advanced selective opening of naphthene rings into slightly branched paraffins of same carbon number.

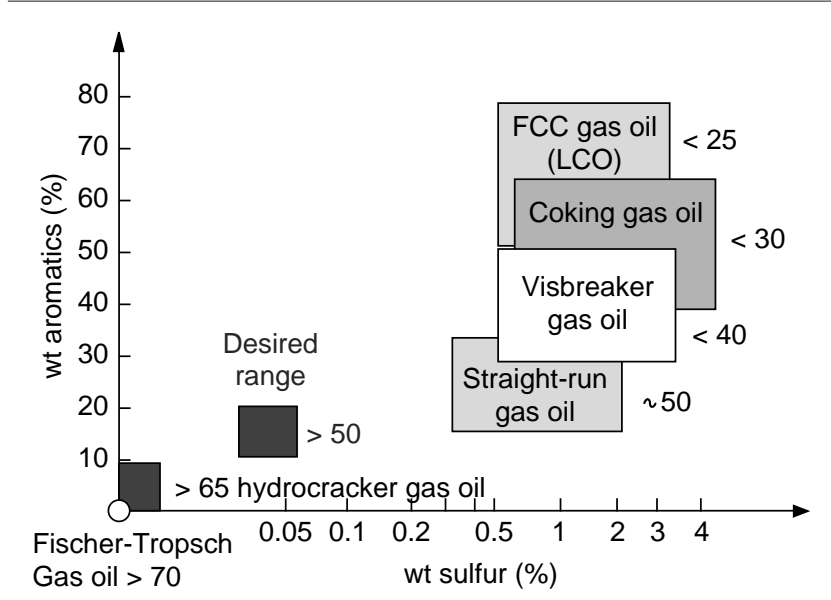

Figure 4

Diesel oil bases of diesel pool (cetane indexes are mentioned on right side of each domain).

TABLE 4

Diesel pool reformulation; main constraints and issues

\begin{tabular}{|c|c|}
\hline Constraints & Issues \\
\hline$\searrow$ Sulfur & $\begin{array}{l}\text { Improved catalysts } \\
\text { Sulfides stable under very low } \mathrm{pH}_{2} \mathrm{~S} \\
\text { Off site sulfiding } \\
\text { Biocatalysis? }\end{array}$ \\
\hline $\begin{array}{l}\text { Aromatics } \\
\text { (thermodynamic } \\
\text { limitations, ...) } \\
\text { High } \mathrm{pH}_{2} \\
\text { Low temperature }\end{array}$ & $\begin{array}{l}\text { Improved catalysts: } \\
\text { - Base metals (high pressure, } \mathrm{H}_{2} \mathrm{~S} \text { ) } \\
\text { - Noble metals/acidic carrier (medium pressure, } \\
\mathrm{H}_{2} \mathrm{~S}>\mathbf{4} \text { ) } \\
\text { - New catalysts with dedicated technologies }\end{array}$ \\
\hline
\end{tabular}

Dimethyl ether is also a possible candidate as a "clean fuel" for DI Diesel engines: its synthesis from methanol was already proven in the methanol-to-gasoline industrial achievements of Mobil. In addition its direct synthesis from syngas is now developed [2] based on a dual catalyst system which process economics are comparable to that of methanol synthesis. Fleet test results show very low $\mathrm{NO}_{\mathrm{x}}$ and particle 
emissions (cetane number $>70$ ). In the future DME could be a possible "LPG equivalent" for dedicated direct injection Diesel engines.

TABLE 5

Two stages IFP's hydrotreating process for pure LCO

\begin{tabular}{l|c|c|c}
\hline & $\begin{array}{c}\text { Feed } \\
\text { LCO }\end{array}$ & $\begin{array}{c}\text { 1st stage } \\
\text { intermediate } \\
\text { products }\end{array}$ & $\begin{array}{c}\text { 2nd stage } \\
\text { final } \\
\text { product }\end{array}$ \\
\hline Specific gravity & 0.942 & 0.873 & 0.856 \\
At $15^{\circ} \mathrm{C}$ & - & - & - \\
Sulfur ppm & 15600 & 3 & $<0.5$ \\
Nitrogen ppm & 1100 & 1 & $<0.5$ \\
Color (ASTM D1500) & 8 & $2-$ & $0.5-$ \\
Aromatics (\%) & 66.4 & 34.2 & 1.4 \\
Cetane Motor (ASTM D86) & 27.5 & 45 & 53.8 \\
Distillation point & 319 & 288 & 283 \\
50 vol.\% ${ }^{\circ} \mathrm{C}$ & - & - & - \\
\hline
\end{tabular}

\section{ECONOMICS AND VIEW ON FUTURE}

Our economical study is focused on Diesel-fuel production with the objective to compare costs of production of FT diesel with that of clean diesel processed from todays SR/LCO Diesel pool and, lastly, to compare these figures with production costs of methanol and DME.

This study is based on the following data:

- production capacity: $30000-50000 \mathrm{bpd}$;

- natural gas available at $\$ 0.6 / \mathrm{MBtu}$;

- capital depreciation: 10 years;

- 80/20 SR/LCO Diesel oil available at \$19/bbl.

Clean Diesel issues from the two-steps IFP's hydrotreating technology of Table 5 (operating pressure lower than $1500 \mathrm{psig}$ ) and DME costs are evaluated from a two step synthesis (methanol then DME).

Diesel fuel properties sought after for both FT product and clean Diesel from SR/LCO HDT are described in Table 6.

TABLE 6

Economical study; properties of final products

\begin{tabular}{l|c|c|c}
\hline Diesel fuel properties & Cetane & $\begin{array}{c}\text { Sulfur } \\
(\mathrm{ppm})\end{array}$ & $\begin{array}{c}\text { Aromatics } \\
(\%)\end{array}$ \\
\hline FT & $>70$ & 0 & 0 \\
\hline $\begin{array}{l}\text { Clean diesel } \\
\text { from SR/LCO HDT }\end{array}$ & 57 & 5 & $<10$ \\
\hline
\end{tabular}

Our results are summarised in Table 7 which details the lowest investments and production costs based on available technologies.
TABLE 7

Investment and cost of production (range of capacities: $30000-50000 \mathrm{bpd}$ )

\begin{tabular}{l|c|c|c|c}
\hline & $\begin{array}{c}\text { FT } \\
\text { Diesel oil }\end{array}$ & Methanol & $\begin{array}{c}\text { DME } \\
(2 \text { steps })\end{array}$ & $\begin{array}{c}\text { Clean } \\
\text { GO }\end{array}$ \\
\hline $\begin{array}{l}\text { Investment } \\
\$ / \mathrm{bbl}\end{array}$ & 35000 & 16000 & 38000 & 5150 \\
\hline $\begin{array}{l}\text { Cost of production } \\
\$ / \mathrm{bbl}\end{array}$ & 24 & 11 & 21 & 24 \\
\hline
\end{tabular}

It appears that FT Diesel oil and clean gas oil have equivalent costs of production. Methanol is much cheaper. The direct synthesis is expected to lower the production cost of dimethyl ether since its lower heating value hampers DME with reference to conventional fuels.

In view of investments the syngas route implies the higher figures. Should a return on investment be needed, FT product prices would increase more rapidly than for clean gas oil. Hence, even in the case of reduced costs for FT synthesis the challenge remains open considering that refining industry usually generate low margins which makes difficult to make high investment projects profitable.

Lastly, it seems worthwhile to compare the expected changes in world oil refining, transport fuel and middle distillate figures to those of today's methanol and tomorrow's Fischer Tropsch middle distillates possible production (Table 8).

TABLE 8

Comparative production figures $(\mathrm{Mt})$; $\mathrm{FT}+$ methanol vs. oil refining

\begin{tabular}{l|c|c|c|c}
\hline & $\mathbf{1 9 7 1}$ & $\mathbf{1 9 9 5}$ & $\mathbf{2 0 1 0}$ & $\mathbf{2 0 2 0}$ \\
\hline Total oil primary consumption & 2448 & 3324 & 4468 & 5264 \\
Transportation sector & 836 & 1520 & 2223 & 2698 \\
Share of transports (\%) & 34 & 46 & 50 & 51 \\
Middle distillates & 610 & 1200 & 1700 & 2000 \\
Middle distillates from FT & - & - & 5 & $>150 ?$ \\
Methanol & ND & 25 & 29 & 30 \\
\hline
\end{tabular}

Source: IFP from 1998 IEA World Energy Outlook

Indeed the growth of oil refining will continue and an increased fraction will be dedicated to transport fuels. Hence, a demand of $2.7 \mathrm{Gt}$ of transport fuels is predicted for year 2020.

In the same time the growth of methanol production should be limited as recent MTBE's ban in the United States do not constitute incentives. FT growth should not start before years 2000-2010 provided that oil prices recover.

In the years 2010 to 2020 , FT middle distillates production could contribute to the increase in demand for clean middle distillates. A scenario where very clean Diesel fuels have to be produced could lead to a potential FT Diesel oil 
use of more than $100 \mathrm{Mt} / \mathrm{y}$. At that time, FT Diesel could issue as a very attractive cetane booster, drastically reducing impurities of the diesel pool and improving its overall performance .

\section{CONCLUSION}

Reformulation of fuels needs significant improvements in the refining industry and appeals for alternative fuels from the syngas chemistry (ethers, FT fuels, etc.). Several technical issues have been presented. More and more technological challenges emerge besides catalysis challenges.

"High specification" demand for both gasoline and Diesel oil makes mandatory to find out advanced solutions for:

- aromatics content reduction in gasoline;

- upgrading (at economical cost) LCO's to high quality Diesel oil;

- producing the tenfold more hydrogen demand for hydropurification and hydroconversion whilst taking into consideration that $1 \mathrm{t}$ of $\mathrm{H}_{2}$ produced implies 7-8 $\mathrm{t}$ of emited $\mathrm{CO}_{2}$ [8];

- improving technologies (syngas production) and catalysts (FT, DME, etc.) within NG upgrading issues.

At present clean fuels (from natural gas, via syngas) do not really compete with reformulated fuels (from oil) since the former counts a few percent of the latter.

However, ethers have open the way to gasoline blending with oxygenated fuels and in the future DME, as a new comer, might induce the development of dedicated DI Diesel engines.
More and more Fischer-Tropsch technology will develop since its diesel cut might be the best available Diesel fuel improver in the market (cetane number and purity) provided that significant savings occur on syngas and FT technology.

\section{ACKNOWLEDGMENTS}

The authors wish to thank J.F. Gruson for his kind contribution in this paper.

\section{REFERENCES}

1 Chaumette, P. (1996) Revue de l'Institut français du pétrole, 51, 711, septembre-octobre 1996.

2 Sorenson, S.C. and Mikkelsen, S.E. (1995) SAE technical paper series, No. 950064. International SAE Congress, Detroit, February 27-March 2, 1995.

3 Sanfilippo, D. (1998) Preprints of 13th Gas convention PDVSA Quimica - AVPG Valencia, May 6-8, 1998.

4 Courty, Ph., Chaumette, P., Raimbault, C. and Travers, Ph. (1990) Revue de l'Institut français du pétrole, 45, 561.

5 Van Wechem, V.M.H. and Senden, M.M.G. (1994) Studies in Surface Science and Catalysis, 81, 43-71.

6 Christensen, T.S. and Primdhal, I.I. (1994) Hydrocarbon Processing, 39, March 1994.

7 Koseoglu, R., Duée, D.D. and Billon, A. (1997) In Upgrading Heavy Ends with IFP, IFP ed, 75-82.

8 Sigault, B. (1998) European Oil Refining Conference and Exhibition, Prague, June 25-26, 1998.

Final manuscript received in May 1999 